\title{
The China-Latin America Axis: Following the Path of the Manila Galleon
}

\author{
Gaston Fornes, University of Bristol, UK, and ESIC Business and Marketing School, Spain \\ Alan Butt Philip, University of Bath, UK
}

The Manila Galleon, the first Link between China and Latin America, created a strong relation between the Middle Kingdom and the then New World. The Manila Galleon (also known as "Nao de China" or "Nao de Acapulco") was the name given to the Acapulco (Mexico)-Manila (Philippines) route established by the Spanish in 1565 for the trade between the New World (America) and the East Indies (Philippines). It was the first global trade route and the longest of its time until it was closed in 1815. The route was nourished in the West by merchants mainly from Fujian (China) trading spices, porcelain, ivory, lacquerware, processed silk cloth and other valuable commodities to be sold in America and/or in Europe as the route continued to Seville (Spain) overland through Mexico (Ruescas \&Wrana, 2009). These goods were mostly bought with silver mined in America, a valuable commodity in the Ming period in China when silver ingots were used as a medium of exchange. In fact, it is estimated that around one-third of the silver extracted from America during this period was shipped to Asia in the galleons (Metropolitan Museum of Art, 2013). After these 250 years of flourishing Asia-America relations, trade between the regions halted with the closure of the route.

A second link started in the 1980s after China changed its foreign policy towards Latin America and many Latin American countries recognised

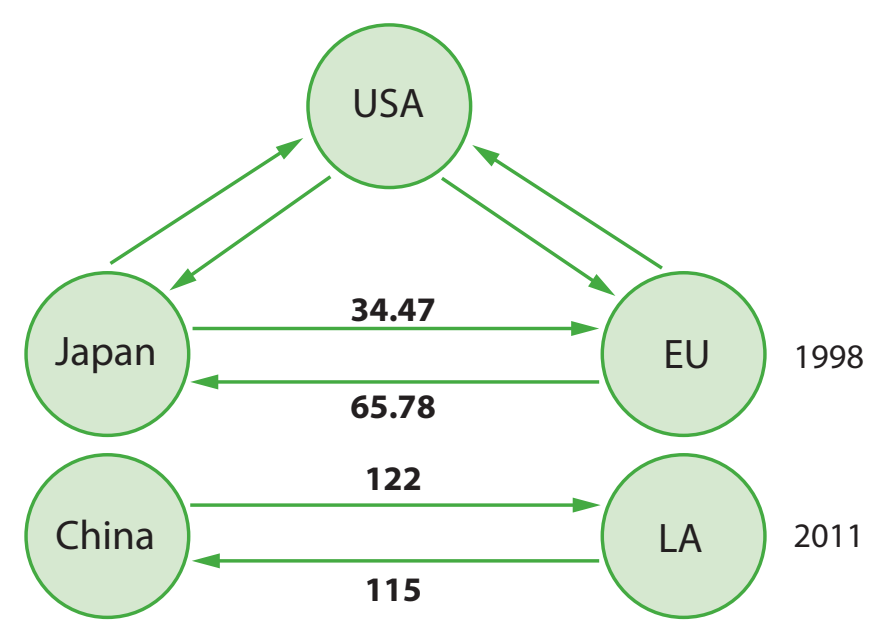

Figure 1: China-Latin America in context - billions of US\$ (Eurostat, 2006; WTO, 2012) the People's Republic of China. This new link has become one of the fastest growing commercial relations in recent history, with trade flows growing at around 50 percent a year (bilateral trade in 1995 was around $\$ 5 \mathrm{bn}$, reaching $\$ 240 \mathrm{bn}$ in 2011; WTO, 2012). This trade axis is bigger than that between the EU and Japan at the end of the 1990s and as such rivals the traditional axes of the Triad (USA, Japan, EU) as can be seen in Figure 1. This axis of trade is growing in both directions (different from what is being seen in China and Africa) and is based on complementary trade partners, exchanging natural resources and low/ medium technology manufactures. It seems that the re-emergence of China on the world stage is not only creating a multi-polar world, but it is also bringing back ancient trade routes like the Manila Galleon or the Silk Road.

\section{An ancient trade route in a multi-polar world}

Different from the Manila Galleon that was led by a European centre, the new China-Latin America axis is changing the dynamics of world trade by developing a strong South-South link of investments and trade that for the first time advanced economies "do not see." In addition to the increased trade, the new axis is having an impact on the following areas: (1) Latin America relations with the US and the EU, (2) regional integration in Latin America and (3) international expansion of both Chinese and Latin American-based MNCs.

\section{Latin America's commercial relations with the US and the EU}

Projected Latin American imports from the US show a substantial decrease from around 33 percent in 2010 to 26 percent in 2020. They also show that China will overtake the EU as the second largest source of imports for Latin America as soon as 2014 or 2015, reaching a 16 percent share in 2020 (14 percent for Europe). Similarly, projected exports also show a substantial decrease of the US's share from around 38 percent in 2010 to 28 percent in 2020 with an increase in China's share to 19 percent in 2020 taking the second position from the EU (13.5 percent in 2020) in the same period. In addition, currently both China and Latin America represent less than 10 percent of trade for each other; it is expected that this share will increase to $18-20$ percent in the next 5-8 years (Barcena \& Rosales, 2010; Fornes \& Butt Philip, 2012; WTO, 2012). 
In terms of investments, since the beginning of the century Latin America has been one of the main destinations of Chinese ODI after Hong Kong. In this context the PRC has committed investments of around US\$100 billion in the region by 2015; and with another $\$ 10$ billion to $\$ 20$ billion of projects announced every year China will overtake Spain (with a stock of around $\$ 140$ billion) as the second largest foreign investor in the region in the coming years (ECLAC, 2011; MOFCOM, 2012; UNCTAD, 2012). There are different reasons for these investments, such as controlling assets, securing the supply of natural resources, getting access to the market (of almost 600 million people and a \$4 trillion economy), using tax havens as a stopover in their onward journey or basing listing vehicles (Fornes \& Butt Philip, 2012; Shixue, 2007).

As a result of this trade and investment, China will acquire substantial soft power, politically as well as economically, as it settles down to be the major development partner of most Latin American states over the next decade. New roads, bridges, ports, factories, telecoms infrastructure, financial services, refineries, mines, quarries, etc. will be the iconic results. The relationship with China for many Latin American states will be transformative, a source of "concern" for the US as well as for some of the Latin American states who are themselves beneficiaries. The concerns are that such developments will meet the needs of China and Chinese investors, but will potentially also set back the more balanced development strategies of Latin American governments.

\section{Regional integration in Latin America}

Regional integration has been the ambition of almost all Latin American states for many decades. There have been initiatives such as the Free Trade Area of the Americas (FTAA) agreement of 1994, which covered
The regional integration efforts that brought into being the UNASUR in the 2010s seem to be weakened by the arrival of the new Chinese traders and investors in the region. This new Chinese dimension strengthens the bilateralism which already characterises most Latin American states' foreign and external trade policies, and that in turn undermines efforts to strengthen integration. Such has been the growth of this trade and investment with China since the 1980s that any improvement in intraregional economic interdependence seems insignificant by contrast. In this context, it is possible to surmise that over time China, by adopting a similar strategic approach to the region of Latin America as a whole, could achieve by accident rather than by design some of the regional economic integration that Latin American states are seeking, perhaps by pressing for measures at the regional level that might simplify or make more efficient its own economic activities or operations. So far there is no evidence that this is happening, and the verdict on China's impact on regional integration in Latin America so far is in the negative.

\section{International expansion of both Chinese and Latin American- based MNCs}

Chinese and Latin American MNCs found in their counterpart a market with relative low entry barriers in comparison with those in the EU and the US. This is the result of free trade agreements signed with Chile (2004), Peru (2007) and Costa Rica (2010), of trade and investment agreements with Brazil (2004), Argentina (2004) and Venezuela (2007), and of China's Policy Paper on Latin America and the Caribbean (Gov.cn, $2008^{1}$ ). In addition, and more importantly, governments are finding quick and friendly responses to any dispute they are encountering in their relation; evidence of this is the lifting of trade barriers for Brazil to sell more processed agricultural goods to China in 2011. This environment means that Latin American companies can sell their goods in China (especially agricultural products where they have comparative and competitive advan-

almost all of America, North and South, the Andean Pact of 1969, and above all Mercosur in 1991; the latter two formally became a part of the Union of South American Nations (UNASUR) in March 2011. However, this integration is still an elusive achievement; the history of the subcontinent helps to explain why. Colonisation confined Latin America to being an exporter of primary products and an importer of manufactured goods. The result was a low diversification of production between the bloc's members, impelling a stronger orientation towards the industrialised countries of the northern hemisphere rather than any forging of trade or other economic links with their neighbours. Thus the economic motivation for regionalism at the outset was far weaker in South America than, for example, in western Europe (Mukhametdimov, 2007). tages) when they are not allowed to compete freely in the EU due to the Common Agricultural Policy (CAP) or in the US due to the agricultural subsidies; it also means that Chinese companies can find in Latin America a growing middle class for their low and intermediate technology manufactures (Fornes \& Butt Philip, 2012; Williamson, Ramamurti, Fleury, \& Leme Fleury, 2013).

In this context, the main challenge for Latin American MNCs (the socalled Multilatinas) is that in general they still suffer from a problem of competitiveness when compared with Asia as their rates of accumulation of physical and human capital are relatively low resulting in a low productivity of factors and less innovation capacity (Maloney \& Perry, 
2005). For this reason, the Multilatinas need to continue diversifying their offer (from the traditional commodities like iron, oil, soya, etc.) as they have been doing in the last two decades (when the commodities' share of total exports was reduced from 50 percent to less than 30 percent) if they want to continue growing sustainably (Cuervo-Cazurra, 2008). However, the demand from China, mainly for natural resources, seems not to be helpful for this purpose. China has replaced the US as the main destination for Brazilian oil and is also a leading destination for Brazilian soybeans and chemical wood pulp, but the demand for passenger cars, Brazil's main manufactured export, seems to be small in the Asian country.

On the other hand, Chinese MNCs (the so-called Dragons) have followed two main stages in their investments in Latin America (Fornes \& Butt Philip, 2012). The first stage, from around 2001 to 2007, was dominated by Chinese SOEs looking for natural resources, presumably with strong support from the government, creating a trade surplus for South American countries. The second stage, from 2007 onwards, is the result of efforts made by small, medium and large companies mainly in the manufacturing sector that have been successfully exporting their products to Latin American markets. These companies are taking the next steps in their internationalisation process in the short- and mediumterms, going from exporting, to contracting, and now FDI. This means that Chinese MNEs are acquiring strategic assets and capabilities extending their value chains to Latin America with, for example, the acquisition of local brands, distribution channels or retail services to market their products. These companies are facing the following challenges in Latin America: (1) they are operating in a region where the presence of ethnic Chinese networks is still low (South America may be one of the few places in the world where it is difficult to find Chinatowns!); (2) Latin America presents an important psychic distance with China; (3) trade and investments are geographically dispersed in a large continent where communications are not easy; and (4) Chinese companies operate in a relatively centralised fashion which could eventually prevent them from making decisions locally and adapting smoothly to changes in the business environment.

\section{Samba with the dragon?}

The new relative position of China in the world has led to a big temptation to dance with the dragon, but this has also led to a difficult question: where can the dragon take you? In the case of Latin America, the relationship with China seems to have benefited most of the region so far, but it is not benefiting all players equally. Flows of trade and investment from China are likely to continue at similar levels, which will surely unveil Latin American firms' weaknesses. At the same time China's companies are strengthening their competitive position in the region. In addition, China's bilateralism can hinder Latin American efforts to increase their economic integration and gain more weight on the world stage.
In other words, China is in Latin America to stay, and it is not clear how internal (Latin American countries) or international (mainly the US, the EU and Japan) players will react, or more importantly, if they have the strength to react and compete with China.

In addition, the new trade axis has flooded the treasuries of Latin American countries with US dollars coming from an increased economic activity and especially from the big jump in the price of commodities. This has led most countries to run fiscal surpluses, which are then used to increase the welfare of citizens. But, in general, this positive economic wave has not been enough to effect a change in the Latin American economic and development model; this has been mainly due to political reasons and the short-sighted vision of many of the governments. The only exception may be Chile, which has set up a sovereign fund based overseas with the excess income coming from the high price of copper, which will be invested in the long-term development of a new economic model; Brazil is attempting to do something similar. This raises the question about the model Latin Americans want for the growth and development of their region. Do they want to continue relying on the exports of primary products? Or are they going to use this opportunity to add more value to the abundant resources in the region?

Similar questions on the future development model could be raised for the Multilatinas. They have enjoyed a decade of growth fuelled by high commodity prices and low cost of capital, and some of them are start-

\section{(S) The future competition for markets will be in emerging economies, but what is not yet clear is where Multilatinas are placed for this battle.}

ing to go international. But this process is still far from being a strong trend. The future competition for markets will be in emerging economies, but what is not yet clear is where Multilatinas are placed for this battle. While deciding what to do, Latin American managers need to recognise that Chinese firms are more than low cost manufacturers; they have the economic muscle of the Chinese government, they have access to the financial markets and they also have a set of capabilities that are becoming stronger as they grow.

In the meantime, history repeats itself. The relationship between China and Latin America that re-started in the 1980s is following the path of the Manila Galleon. Natural resources are going to China to feed the pillars of its economic development, while Latin American markets are being flooded with consumer products manufactured in the Middle Kingdom. Latin America is as economically fragmented as in the past, with integration being a moving target weakened by the pursuit of bilateral relations with China. And Multilatinas, although in a better shape than some years ago, still need to demonstrate their weight in the in- 
ternational arena by moving up in the value chain. The only difference is that now this is happening in a multi-polar world, and as such no Western economy is involved.

\section{References}

Barcena, A., \& Rosales, O. 2010. La República Popular China y América Latina y el Caribe: hacia una relación estratégica. Santiago de Chile: ECLAC.

Cuervo-Cazurra, A. 2008. The multinationalization of developing country MNEs: The case of multilatinas. Journal of International Management, 14(2): 138-154.

ECLAC. 2011. Foreign Direct Investment in Latin America and the Caribbean 2010. Santiago: Economic Commission for Latin America and the Caribbean.

Eurostat. 2006. European Business Facts and Figures. Brussels: European Commission.

Fornes, G., \& Butt Philip, A. 2012. The China-Latin America Axis. Emerging markets and the future of globalisation. Basingstoke: Palgrave Macmillan.

Gov.cn. 2008. http://www.gov.cn/english/official/2008-11/05/content 1140347.htm. Last accessed on 20/4/2011.

Maloney, W., \& Perry, G. 2005. Towards and efficient innovation policy in Latin America. ECLAC Review, 87: 25-43.

Metropolitan Museum of Art. 2013. http://www.metmuseum.org/toah/ hd/mgtr/hd mgtr.htm. Last accessed on 28/3/2013.

Gaston Fornes holds a joint Senior Lecturer position between the Centre for East Asian Studies, University of Bristol (UK) and ESIC Business and Marketing School (Spain); in the latter he is also the China Centre Director. Dr Fornes has published widely on management in emerging countries, and for his work with Chinese SMEs he received the Liupan Mountain Friendship Award from the Ningxia Government (China) for his "contribution to Ningxia's economy and society". $\mathrm{He}$ is visiting professor at Nanjing University, Shanghai International Studies University, Shanghai University, and Southwestern University of Finance and Economics; he has also taught at the Party School of the Communist Party of China. He is Senior Fellow of the UK Higher Education Academy. Dr Fornes has reached summit in the Andes and runs marathons.
MOFCOM. 2012. Statistical Bulletin of China's Outward Foreign Direct Investment. Beijing: Ministry of Commerce the People's Republic of China.

Mukhametdimov, M. 2007. Mercosur and the European Union: variation among the factors of regional cohesion. Cooperation and Conflict, 42: 201-225.

Ruescas, J., \& Wrana, J. 2009. The West Indies \& Manila Galleons: the First Global Trade Route. Paper presented at The Galleon and the Making of the Pacific, Manila.

Shixue, J. 2007. South-South Cooperation across the Pacific: Development of the Relations between China and Latin American. Beijing: Chinese Academy of Social Sciences.

UNCTAD. 2012. http://unctadstat.unctad.org/TableViewer/tableView. aspx?Reportld=88. Last accessed on 18/10/2012.

Williamson, P., Ramamurti, R., Fleury, A., \& Leme Fleury, M. T. (Eds). 2013. The Competitive Advantage of Emerging Market Multinationals. Cambridge: Cambridge University Press.

WTO. 2012. International Trade Statistics. Geneva: World Trade Organisation.

\section{Endnote}

1 This was the first ever white paper on the region and one of the first to appear on China's relations with international actors in recent decades.
Alan Butt Philip is Honorary Jean Monnet Reader in European integration at the University of Bath (UK). He is also a visiting professor at the Charles University in Prague, and has held visiting professorships at the University of Virginia, the University of Richmond, the Ecole Superieure de Commerce de Paris, and the Technological University of Monterrey. He has been active in UK politics as a Liberal/Liberal Democrat candidate for the House of Commons and the European Parliament over many decades. From 1980 to 1989 he was special adviser to the House of Lords Select Committee on the European Communities responsible for regional policy and the structural funds. He is convenor and a trustee of the John Stuart Mill Institute. 